\title{
感性と構造特性を評価関数とする自転車フレームの最適設計*
}

\author{
下田 昌利 ${ }^{* 1}$, 近藤 晃 ${ }^{* 2}$, 劉 陽 ${ }^{* 1}$
}

\section{Optimum Design of Bicycle Frame Considering Kansei and Structural Performances}

\author{
Masatoshi SHIMODA ${ }^{* 1}$, Akira KONDO and Yang LIU \\ ${ }^{* 1}$ Toyota Technological Institute Dept. of Advanced Science and Technology \\ 2-12-1 Hisakata, Tempaku-ku, Nagoya, 468-8511 Japan
}

This paper presents an optimum design method considering structural performances and Kansei, which has been becoming an important issue for product designs with maturation of consumer demands. The response surface methodology combined with the design of experiment technique is applied to a bicycle frame design problem. The strength and the rigidity calculated by FEM are used as the evaluation functions for the structural performances. Three dimensional rendering models are constructed with computer graphics software, and used for the Kansei evaluation. The Kansei performances such as "individual" and "elegant" are evaluated by the Semantic Differentials technique and quantified. A road-bicycle frame is focused on as an application example of this method. Sizes of the cross section at both ends, position and angle of rotation at the midpoint of each frame are defined as the design variables to be optimized. By using the response surfaces between the design variables and the performances, the form of road-bicycle frame is optimized under various objectives and constraints. The form with the optimized design variables is visualized with the CG software.

Key Words : Structural Optimization, Kansei, Response Surface, SD Technique, Pareto Solution, Bicycle Frame

\section{1. 緒言}

プロダクトデザインにおいて製品の機能や構造特性だけではなく，ユーザーを魅了し，心に響く意匠デザイン やフィット感，接触感などの感性を考慮した設計が益々重要視されている．特に，成熟した消費社会においてそ の傾向は顕著で，性能や機能よりもデザイン性が重視される場合が少なくない．最近では家電製品や乗用車，日 用品等の一般消費者向けの製品に加え，建設機械などの産業製品に対する構造設計においても感性を意識した構 造設計が行われるようになってきている.

感性設計は強度や剛性を扱う構造設計とは異なり，人の主観的な判断が評価関数となり，その設計は設計者や デザイナーのセンスに大きく依存する，感覚的で曖昧さを含むため，定量化や設計の標準化が難しいとされてい る. その定量化手法の一つに感性工学手法II類があり, 多数の感性設計一の適用例が紹介されている(1)(2). 一旦定 量化が行われれば，既に確立されている構造最適化手法との組み合わせが可能となり，感性と構造特性を評価関 数とする多制約，または多目的最適化計算が行える. それにより，お互いにトレードオフの関係にあることが多 い機能や構造特性と感性のパレート解や多数の複雑な制約条件を課した場合の最適解の決定も容易に可能となる.

「感性工学(Kansei Engineering)」に関寸る研究は長町らにより1970年代に始まった「情緒工学」がその起 源とされ(3), それ以降, 自動車, 家電製品, 日常用品, 建築, 土木などの幅広い分野で工業製品の設計に導入さ れてきた．例えば，勝山らは自動車のフロントビューの感性設計に，遺伝的アルゴリズム (Genetic Algorithms)の 適応度の評価にS D 法 (Semantic Differentials technique) による感性評価を用いることにより, 新しい設計を産み 出寸手法を提示している ${ }^{(4)}$. 荒川らは人間が連続的に感性評価を行う場合に最も負担を感じない 2 值比較を基に

* 原稿受付 2013 年 3 月 27 日

${ }^{* 1}$ 正員, 豊田工業大学（广468-8511 愛知県名古屋市天白区久方 2-12-1）

*2 (株) 豊田自動織機

E-mail: shimoda@toyota-ti.ac.jp 
定性的感度を評価し，これを用いて定性的な最適設計を行う手法を提示し，高能率を引き出すV D T 作業用の椅 子の開発に適用している ${ }^{(5)}$. 柳澤らは感性の多様性に着目した感性品質の定量化手法を提案し, 製品音の音質設 計に適用し，多様性を有する感性と共通性の高い感性の定量的な把握を可能にしている(6). 茅原らは「飲みや寸 い」と感じるアルミボトルの口径を探るために，感性工学のS D法に基づいて形容詞（感性ワード）の対語で構 成されるアンケート用紙を作成し, 官能評価実験を行っている(7)(8). 韓らは客観的な人間の感覚評価法として, 有限要素法を利用した数值解析により得られた工学指標と関連させた方法を提案し, 指に優しいホット販売用ア ルミ飲料ボトルの䇶胴の形状設計 ${ }^{(9)}$ や指掛かり性のよい飲料缶の S OT蓋の設計 ${ }^{(10)}$ に適用した. 安達らは感性関 連の目的関数を含む工業製品が具備するすべての商品特性群の目的関数を組み入れた多目的満足計法を提案して いる(11).また，建築分野の空間設計では感性を考慮したデザイン支援システムの構築のため，形容詞とCADデ 一タを用いた形態デザインの創成 ${ }^{(12)(13)}$ や景観画像と C A Dデータベースから調和的な景観を求める研究も行わ れている ${ }^{(14)(15)}$. 土木分野においても画像処理による視覚感性評価の自動化と遺伝的アルゴリズムを利用した橋梁 の意匠設計 ${ }^{(16)}$ や，アーチ橋 ${ }^{(17)}$, 桁橋 ${ }^{(18)}$ などを対象に感性工学手法による感性評価実験を実施し, その分析結果 を利用して橋梁の景観評価や設計支援システムの構築に関寸る研究が行われている. しかし，これらの研究は感 性評価を軸足においた研究であり, 構造解析と感性評価を同時に扱う最適設計に関する研究はほとんど行われて いないようである.

本研究では感性, その中でも意匠性と構造特性の両者が重要な設計ファクターである自転車フレームに着目し た. シンプルな構造であるが，フレームの曲率や断面の大きさはユーザーの感性と構造特性に大きく影響を与え る. 本論文では舗装路での高速走行に特化した自転車であり自転車の中で最も軽量化が進んでいるとされるロー ドバイクのフレーム構造を取り上げ, 各フレームの外径及び曲率を設計変数とし, 感性と構造特性の両者を評価 関数とした最適設計法を提示することを目的とした. 感性はC G（コンピュータグラフィックス）ソフトウェア で制作したモデルを用いて感性工学手法のS D法により定量化し, 剛性や強度の構造特性は有限要素解析によっ て評価した. 感性と構造特性に関する評価関数を複数組み合わせながら制約条件と目的関数を定義し, 単目的, もしくは多目的最適設計問題に対寸る最適なフレームフォルムを応答曲面法(19)(20) と数理計画法を利用して探索 した．続く章にて，手法と計算結果を提示する.

\section{2. 感性を考慮した構造最適設計}

\section{$2 \cdot 1$ 感性と構造特性を考慮した最適化手法}

構造最適化手法は設計目的（設計変数の種類）により大きくトポロジー最適化，形状最適化，寸法最適化に分 類されるが，本論文で扱う自転車フレームのフォルム設計問題はフレームの形状（曲率）と断面のサイズを設計 変数とするため, 寸法と形状の同時最適化問題といえる. 一般に, 最適化問題での解の決定は勾配法に基づく場 合，与えられた初期值に対し，コスト関数（目的関数と制約条件）の評価，及びそれらの設計変数に対する感度 計算を行い，数理計画法による解探索によって設計変数を更新するプロセスを繰り返すことにより行われる. 本 論文で扱う自転車フレームのフォルムデザインでは重量, 剛性, 強度からなる構造特性と「格好いい」,「お酒落」 のような感性に関する評価関数を同時に扱う必要がある.構造特性とその感度計算には有限要素法を用いるため, 設計変数の更新毎の逐次計算が可能であるが，ユーザー評価に基づく感性の評価とその感度計算の逐次的な評価 は困難である. そのため, 事前に設計変数と感性の評価関数との関係を近似関数で表し，その近似関数を用いて 最適化問題を解くことができる応答曲面法を利用することとした. 応答曲面法では設計変数の上限と下限值が事 前に設定され，その範囲内で求められた内挿関数を最適化計算に利用するため, 設計変数の上下限值間での解探 索が行われる.

\section{$2 \cdot 2$ 最適化手法の流れ}

図 1 に提示する手法の全体の流れを示す.まず, フレームのフォルムデザインのための設計変数を決定し, 直 交表に割り付つける. 続いて, 構造特性の評価は直交表の設計変数の組合せに従って有限要素モデルを作成し, 有限要素解析により行う，感性の評価は感性工学手法I類を基に評価寸る感性ワードの調査，決定を行い，それ と並行して評価に用いる 3 次元 C G モデルを構造特性の評価と同様に直交表の設計変数の組合せに従って制作し， 
S D法に基づくユーザーアンケートによって行い，得られた評価結果を基に設計変数と構造特性，感性の評価関 数の関係を応答曲面（推定式）近似する. 次に，得られた応答曲面を組み合わせて単目的や多目的最適設計問題 を定義し，感度計算と数理計画法による解探索を行い，最適設計変数を決定する．最後に，得られた結果を C G ソフトウェアでリモデリングし，デザインの可視化と確認を行う。なお，設計変数はC Gソフトウェア内でパラ メータ化されているため，得られた結果の数值を代入することにより，容易にリモデリングされる.

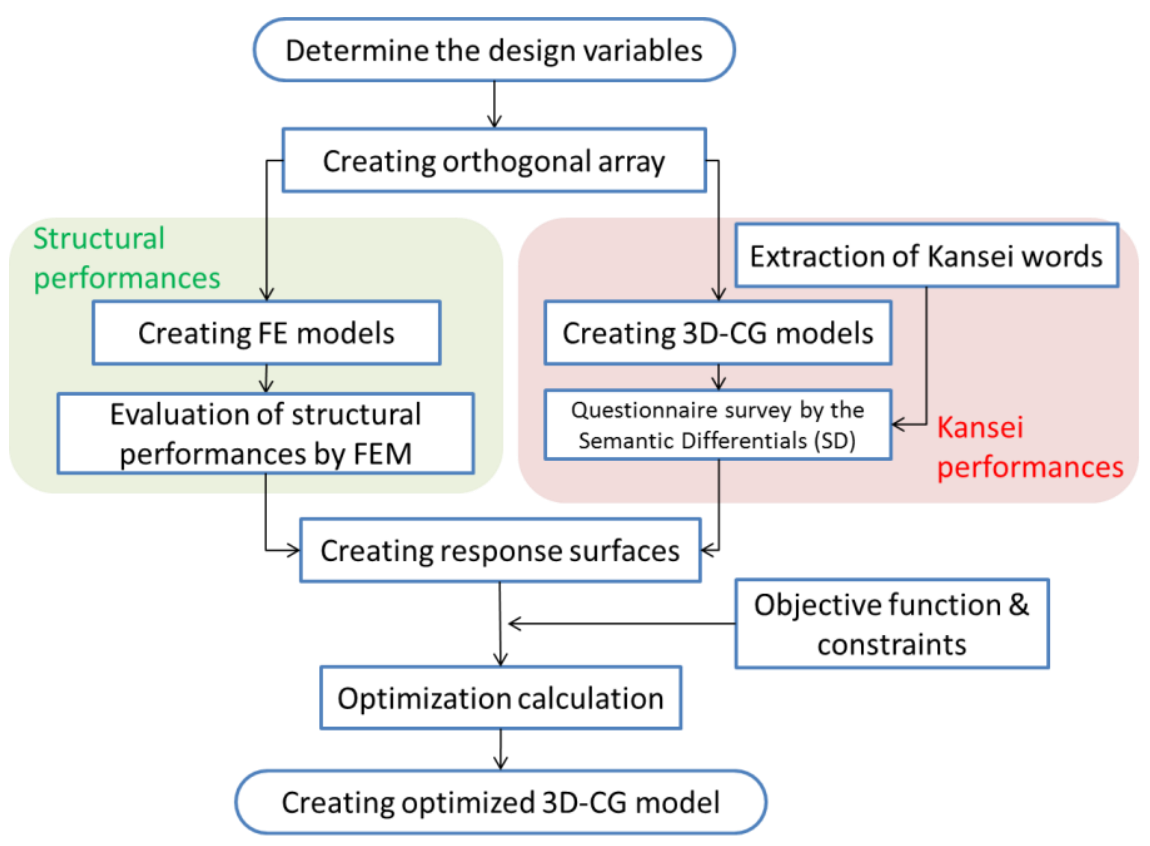

Fig.1 Schematic of optimum design methodology

\section{$2 \cdot 3$ 設計変数（要因）の設定}

対象としたロードバイクは図 2 (a)のように6つのメインフレームからなり，その全 6 レムを設計対象とした. 各フレームは曲線フォルムを可能とするため, ベジェ曲線を用いて表現し，その中央に設定したコントロールポ イントの垂直方向変動量と回転角を設計変数とした。これにより図 2 (b)に示すように垂直方向の変動で放物線型 のフレームフォルム (黄色) が生成され，回転角の変動で $\mathrm{S}$ 字型のフレームフォルム（緑色）が生成される。ま た，フレームはテーパも可能とするため，各フレーム両端の外径を独立設計変数とした. これにより 1 フレーム について 4 つ，合計 24 個の設計変数でフレームフォルムの決定を行うこととした. 定義した設計変数の名称と 水準を表 1 に示すが，設計変数はいずれも 3 水準とし，フレーム両端部外径を $\left(\left(\mathrm{x}_{1}, \mathrm{x}_{2}\right),\left(\mathrm{x}_{3}, \mathrm{x}_{4}\right), \cdots,\left(\mathrm{x}_{11}, \mathrm{x}_{12}\right)\right)$, 中央

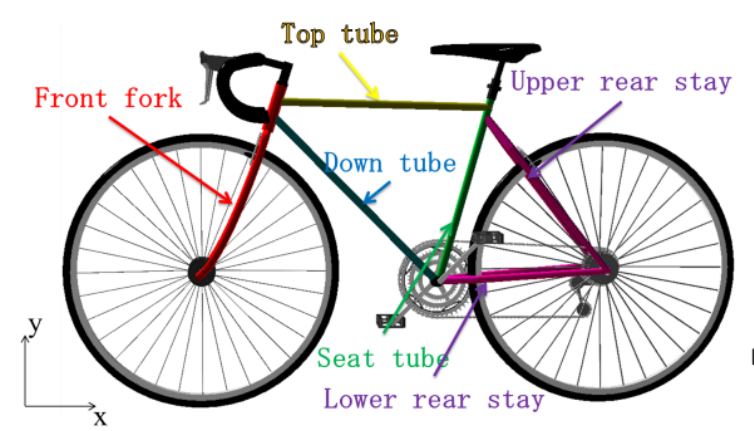

(a) Road-bike model and frames to be designed

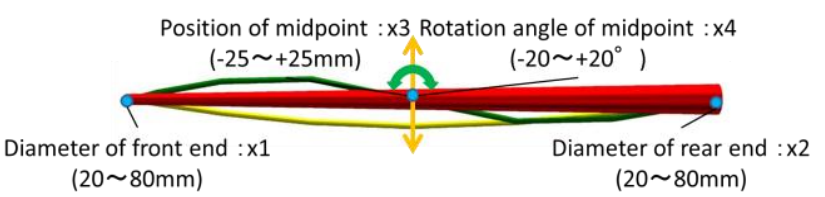

(b) Design variables for one frame

Fig.2 Design variables of road-bike frame 
Table 1 Levels of design variables

\begin{tabular}{|c|c|c|c|c|c|c|c|c|c|c|c|}
\hline Variables & Factors & Parameter & \multicolumn{3}{|c|}{ Levels } & Variables & Factors & Parameter & \multicolumn{3}{|c|}{ Levels } \\
\hline $\mathrm{X}_{1}, \mathrm{X}_{2}$ & Front fork & Diameter & 20 & 50 & 80 & $\mathrm{X}_{16}$ & Top tube & Rotation angle & -20 & 0 & 20 \\
\hline $\mathrm{X}_{3}, \mathrm{X}_{4}$ & Top tube & Diameter & 20 & 50 & 80 & $\mathrm{X}_{17}$ & Down tube & Position & -25 & 0 & 25 \\
\hline $\mathrm{X}_{5}, \mathrm{X}_{6}$ & Down tube & Diameter & 20 & 50 & 80 & $\mathrm{X}_{18}$ & Down tube & Rotation angle & -20 & 0 & 20 \\
\hline $\mathrm{X}_{7}, \mathrm{X}_{8}$ & Seat tube & Diameter & 20 & 50 & 80 & $\mathrm{X}_{19}$ & Seat tube & Position & -25 & 0 & 25 \\
\hline $\mathrm{X}_{9}, \mathrm{X}_{10}$ & Top of the rear stay & Diameter & 20 & 50 & 80 & $\mathrm{X}_{20}$ & Seat tube & Rotation angle & -20 & 0 & 20 \\
\hline $\mathrm{x}_{11}, \mathrm{x}_{12}$ & Bottom of the rear stay & Diameter & 20 & 50 & 80 & $\mathrm{x}_{21}$ & Top of the rear stay & Position & -25 & 0 & 25 \\
\hline $\mathrm{x}_{13}$ & Front fork & Position & -25 & 0 & 25 & $\mathrm{x}_{22}$ & Top of the rear stay & Rotation angle & -20 & 0 & 20 \\
\hline $\mathrm{x}_{14}$ & Front fork & Position & -20 & 0 & 20 & $\mathrm{x}_{23}$ & Bottom of the rear stay & Position & -25 & 0 & 25 \\
\hline $\mathrm{X}_{15}$ & Top tube & Position & -25 & 0 & 25 & $\mathrm{X}_{24}$ & Bottom of the rear stay & Rotation angle & -20 & 0 & 20 \\
\hline
\end{tabular}

コントロールポイントの面外方向の位置を $\left(\mathrm{x}_{13}, \mathrm{x}_{15}, \mathrm{x}_{17}, \mathrm{x}_{19}, \mathrm{x}_{21}, \mathrm{x}_{23}\right)$, 回転角を $\left(\mathrm{x}_{14}, \mathrm{x}_{16}, \mathrm{x}_{18}, \mathrm{x}_{20}, \mathrm{x}_{22}, \mathrm{x}_{24}\right)$ と し，それぞれに対して $(20 ， 50 ， 80[\mathrm{~mm}]) ，(-25 ， 0 ，+25[\mathrm{~mm}]) ，\left(-20,0,+20\left[^{\circ}\right]\right)$ を割り当てた．なお，フレーム は中空の円形断面（板厚 $1[\mathrm{~mm}]$ ） とした. 感性および構造特性の評価を行うため, 24 個の設計変数を表 2 のよ うに $\mathrm{L}_{81}$ 直交表に割り付けた．なお，設計変数間の交互作用は考慮しないこととした。

\section{$2 \cdot 4$ 感性の評価}

感性の評価は直交表に割り付けられた 81 通りの設計変数の組み合わせに基づき作成し，レンダリングを施し たCGモデルに対し，ユーザー（被験者）によるパソコン上での目視評価によって行った. No. 81 の設計変数の 組み合わせを基に作成したC G モデルの例を図 3 (a)に示す.

評価する感性ワードはS D法に従い，まず市販のロードバイクのパンフレットから視覚のみで評価できる形容 詞，すなわち感性ワードを抜き出し，その中から頻出しているものを抽出し，対になっている反対ワードを準備 した.「格好いい」,「お酒落」,「個性的」,「モダン」,「上品」,「速そう」,「高価そう」,「男性的」,「軽そう」,「頑 丈そう」の感性ワードを抽出した. 被験者は大学生（2 2 歳・男性）とし, 図 3 (b)のような調査用紙を準備し, 5段階評定尺度法によるアンケート調査を行った．被験者の母数を多くし，ばらつきを評価しながら平均值を用 いることも可能であるが，今回はロードバイクフレームをユーザーに合わせてカスタマイズすることを想定し， 被験者 1 人のデータのみを用いることとした．得られた調查表の結果から 2 次の直交多項式を用いて各感性ワー ドの設計変数に対する応答曲面を求めた。

Table $2 \mathrm{~L}_{81}$ Orthogonal array

\begin{tabular}{|c||c|c|c|c|c|c|c|c|c|c|c|c|c|c|c|c|c|c|c|c|c|c|c|c|}
\hline Model & $\mathrm{x}_{1}$ & $\mathrm{x}_{2}$ & $\mathrm{x}_{3}$ & $\mathrm{x}_{4}$ & $\mathrm{x}_{5}$ & $\mathrm{x}_{6}$ & $\mathrm{x}_{7}$ & $\mathrm{x}_{8}$ & $\mathrm{x}_{9}$ & $\mathrm{x}_{10}$ & $\mathrm{x}_{11}$ & $\mathrm{x}_{12}$ & $\mathrm{x}_{13}$ & $\mathrm{x}_{14}$ & $\mathrm{x}_{15}$ & $\mathrm{x}_{16}$ & $\mathrm{x}_{17}$ & $\mathrm{x}_{18}$ & $\mathrm{x}_{19}$ & $\mathrm{x}_{20}$ & $\mathrm{x}_{21}$ & $\mathrm{x}_{22}$ & $\mathrm{x}_{23}$ & $\mathrm{x}_{24}$ \\
\hline \hline 1 & 20 & 20 & 20 & 20 & 20 & 20 & 20 & 20 & 20 & 20 & 20 & 20 & -25 & -20 & -25 & -20 & -25 & -20 & -25 & -20 & -25 & -20 & -25 & -20 \\
\hline 2 & 20 & 20 & 20 & 50 & 20 & 20 & 20 & 50 & 50 & 50 & 20 & 20 & -25 & -20 & 0 & 0 & 0 & 0 & 0 & 0 & -25 & -20 & 0 & 0 \\
\hline 3 & 20 & 20 & 20 & 80 & 20 & 20 & 20 & 80 & 80 & 80 & 20 & 20 & -25 & -20 & 25 & 20 & 25 & 20 & 25 & 20 & -25 & -20 & 25 & 20 \\
\hline
\end{tabular}

\begin{tabular}{l}
\hline 101010 \\
\begin{tabular}{|c||c|c|c|c|c|c|c|c|c|c|c|c|c|c|c|c|c|c|c|c|c|c|c|c|}
\hline 80 & 80 & 80 & 80 & 50 & 50 & 50 & 50 & 20 & 20 & 20 & 20 & 20 & -25 & -20 & -5 & 20 & 25 & 20 & 25 & 20 & 25 & 20 & 0 & 0 \\
\hline 81 & 80 & 80 & 80 & 80 & 50 & 50 & 50 & 50 & 50 & 50 & 20 & 20 & -25 & -20 & -25 & -20 & -25 & -20 & -25 & -20 & 25 & 20 & 25 & 20 \\
\hline
\end{tabular}
\end{tabular}




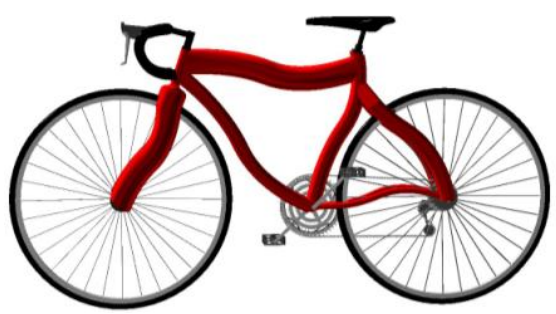

(a) CG model (No.81)

\begin{tabular}{|l|l|l|l|l|l|l|}
\cline { 2 - 7 } \multicolumn{1}{c|}{} & 5 & 4 & 3 & 2 & 1 & \\
\hline Cool & & & & & & Not cool \\
\hline Individual & & & & & & Not individual \\
\hline Fast & & & & & & Not fast \\
\hline
\end{tabular}

(b) Evaluation list

Fig.3 Example of questionnaire

\section{$2 \cdot 5 \quad$ 構造特性の評価}

構造特性の評価は感性評価と同様， $\mathrm{L}_{81}$ 直交表を基に図 4 (a)のような 3 次元はり要素モデルを作成し，有限要 素法による構造解析により行った。構造解析における境界条件は J I S を参考に図のようにフレームの両端をピ ン支持し，サドル部分，ハンドルポスト部，ペダルクランク軸部にそれぞれ下向きに $500 ， 100 ， 250(\mathrm{~N})$ の力を与 えた ${ }^{(21)}$. 有限要素計算によって得られた変形モードの例を図 4 (b)に示す. 構造特性に関する評価は負荷点 $\mathrm{A} の$ 変 位，重量および高応力となるフレーム結合部（A， B， C 点）での応力とし，曲げ応力と軸応力を重ね合わせた 值を用い，各点での最大值をその点での応力值とした。 感性評価と同様，得られた值を用いて 2 次の直交多項式 による各構造特性の応答曲面を求めた.

なお, 構造特性と感性とのスケールを合わせるため, 感性と構造特性評価において得られた結果を 0.01 から 0.99 の範囲で基準化した．例えば， C 点での応力評価の場合， 81 モデル中の最大值と最小值を抽出し，それぞれ $\sigma_{c \text { max }}=49.20(\mathrm{MPa}), \quad \sigma_{c \text { min }}=2.21(\mathrm{MPa})$ として, 式(1)に適用した. 今回, データの他解析での利用のため 0.01 から 0.99 での基準化としたが，0から 1 での基準化による応答曲面と変わりないことを確認している.

$$
\frac{\sigma_{i}-\sigma_{\min }}{\sigma_{\max }-\sigma_{\min }} \times 0.98+0.01
$$

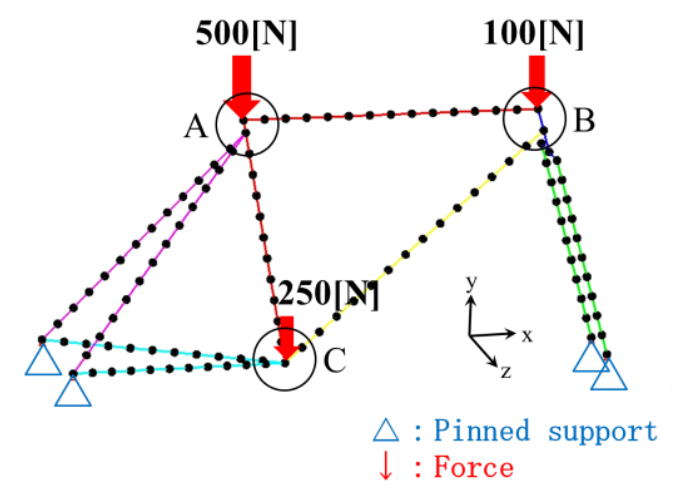

(a) FEM model

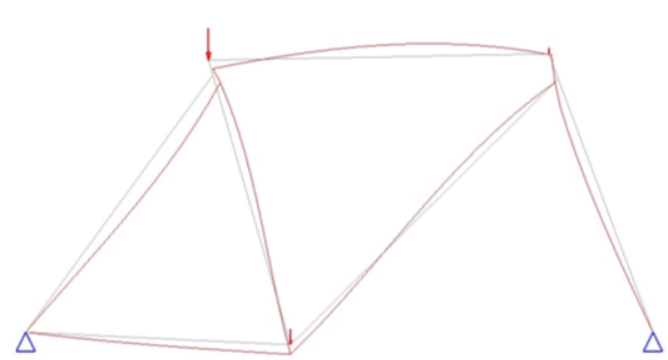

(b) Deformation mode

Fig.4 FE calculation of road-bike frame

\section{3. 計算結果}

\section{$3 \cdot 1$ 応答曲面（推定式）}

求めた感性と構造特性の 2 次応答曲面のうち, 「格好いい」,「お酒落」,「C 点応力」, 「重量」の例を式(2)から 式(5)に示寸．なお，寄与の少ない $\mathrm{F}_{(0.05)}$ 以下の項をプーリングしている．また，評価データと求めた応答曲面の 比較を図 5 に示寸．ここで， $\mathrm{x}$ 軸はモデル番号，y軸は特性值をそれぞれ示している. 青の棒グラフは構造解析や 
アンケート結果などの評価データ, 赤の折れ線グラフは求めた応答曲面による推定值を示す．図 5 からいずれの 特性も十分な精度で近似できていることがわかる.

Cool:

$f\left(x_{1}, x_{2}, \ldots, x_{24}\right)=-1.028807 \times 10^{-5}-1.234568 \times 10^{-3} x_{1}+6.606996 \times 10^{-3} x_{5}-7.057613 \times 10^{-5} x_{5}^{2}-1.289609 \times 10^{-2} x_{11}$ $+1.204733 \times 10^{-4} x_{11}{ }^{2}+1.047737 \times 10^{-2} x_{3}-7.119342 \times 10^{-5} x_{3}{ }^{2}+7.50823 \times 10^{-3} x_{6}-7.057613 \times 10^{-5} x_{6}{ }^{2}$ $-1.385803 \times 10^{-3} x_{7}+7.37037 \times 10^{-4} x_{21}-1.251852 \times 10^{-4} x_{21}^{2}-1.597222 \times 10^{-3} x_{14}-2.650463 \times 10^{-4} x_{14}^{2}$ $+9.166666 \times 10^{-4} x_{22}-1.601852 \times 10^{-4} x_{22}{ }^{2}+1.315638 \times 10^{-2} x_{4}-8.600823 \times 10^{-5} x_{4}{ }^{2}+4.866667 \times 10^{-3} x_{15}$ $-1.074074 \times 10^{-4} x_{17}+1.068148 \times 10^{-4} x_{17}^{2}+2.263889 \times 10^{-3} x_{20}$

Stylish:

$$
\begin{array}{rl}
f\left(x_{1}, x_{2}, \ldots, x_{24}\right)=0 & 0.2320988-9.355967 \times 10^{-3} x_{2}+8.127572 \times 10^{-5} x_{2}{ }^{2}+6.745885 \times 10^{-3} x_{5}-7.890946 \times 10^{-5} x_{5}{ }^{2} \\
& +1.682099 \times 10^{-3} x_{3}-1.92963 \times 10^{-3} x_{13}-2.041667 \times 10^{-3} x_{14}-3.31713 \times 10^{-4} x_{14}{ }^{2}+1.152778 \times 10^{-3} x_{22} \\
& -1.622685 \times 10^{-4} x_{22}{ }^{2}+1.180761 \times 10^{-2} x_{4}-7.76749 \times 10^{-5} x_{4}{ }^{2}+3.392593 \times 10^{-3} x_{15}+1.952593 \times 10^{-4} x_{15}{ }^{2} \\
& -1.361111 \times 10^{-3} x_{9}-1.466667 \times 10^{-3} x_{23}-1.814815 \times 10^{-4} x_{17}+2.49037 \times 10^{-4} x_{17}{ }^{2}-1.490741 \times 10^{-3} x_{24} \\
& -1.782407 \times 10^{-4} x_{24}{ }^{2}+2.282407 \times 10^{-3} x_{20}
\end{array}
$$

Stress at C:

$$
\begin{aligned}
f\left(x_{1}, x_{2}, \ldots, x_{24}\right)= & 0.3101234+7.380658 \times 10^{-3} x_{5}-4.917695 \times 10^{-3} x_{5}{ }^{2}+2.432099 \times 10^{-3} x_{6}+2.192592 \times 10^{-3} x_{21} \\
& +3.388889 \times 10^{-3} x_{14}-1.453704 \times 10^{-4} x_{14}{ }^{2}+6.386831 \times 10^{-3} x_{9}-5.843621 \times 10^{-5} x_{9}{ }^{2}+1.340741 \times 10^{-3} x_{17} \\
& +5.485597 \times 10^{-3} x_{10}-4.73251 \times 10^{-5} x_{10}{ }^{2}
\end{aligned}
$$

Weight:

$f\left(x_{1}, x_{2}, \ldots, x_{24}\right)=+1.45-2.154321 \times 10^{-3} x_{1}-2.006173 \times 10^{-3} x_{2}-1.580247 \times 10^{-3} x_{5}-2.246914 \times 10^{-3} x_{11}-1.308642 \times 10^{-3} x_{3}$

$-1.438272 \times 10^{-3} x_{6}-2.141975 \times 10^{-3} x_{12}-1.141975 \times 10^{-3} x_{7}-1.327161 \times 10^{-3} x_{4}-1.141975 \times 10^{-3} x_{8}$ $-2.58642 \times 10^{-3} x_{9}-2.666667 \times 10^{-3} x_{10}-6.666667 \times 10^{-5} x_{19^{-}}-2.281481 \times 10^{-5} x_{19}{ }^{2}$

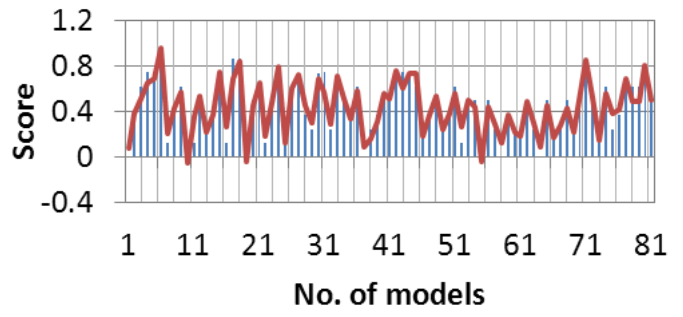

(a) Cool

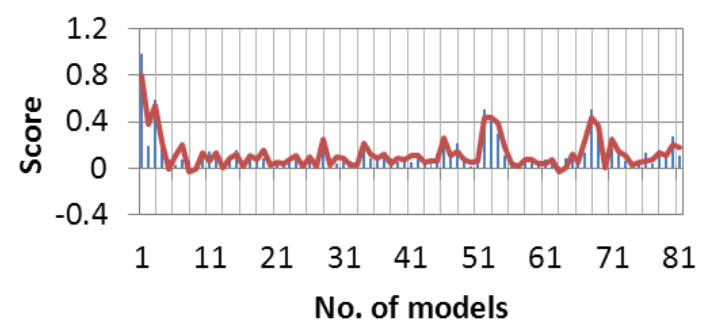

(c) Stress at C

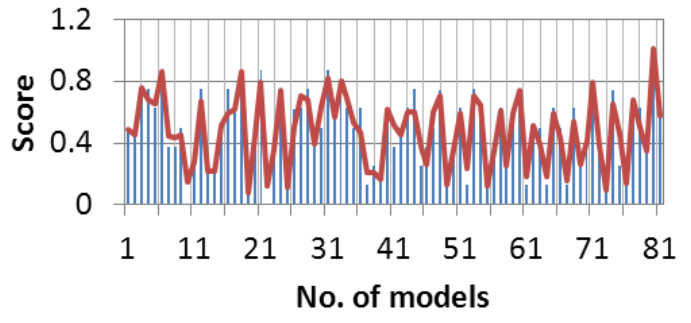

(b) Stylish

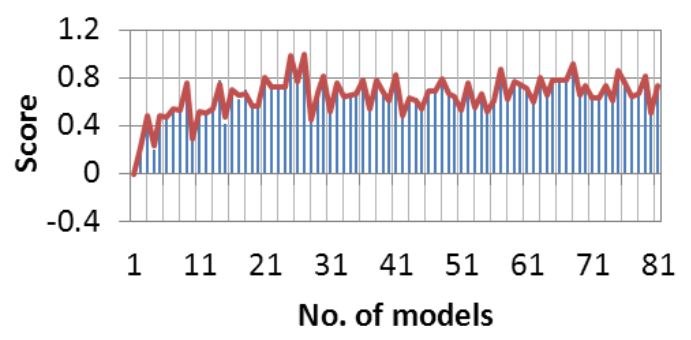

(d) Weight

Fig.5 Comparison of response surface (blue:original, red:estimated) 


\section{$3 \cdot 2$ 単一目的の最適化計算結果}

感性と構造特性から単一の目的関数と複数の制約条件を設定し，4 ケースの最適化解析を行った．なお，本節 の全ての計算ケースにおいて, 最適化手法としては逐次 2 次計画法を用い, 初期值は各水準の中央値とした.

\section{$3 \cdot 2 \cdot 1$ 応力の最小化 (ケース 1$)$}

まず，構造特性の 1 つである C 点応力の最小化を目的に, 設計変数に式(6)から式(8)の側面制約を与えて最適化 計算を行った.

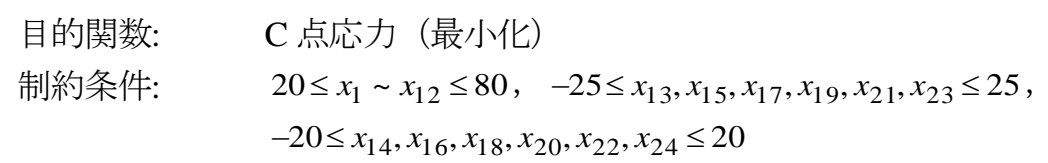

初期值と得られた最適化結果を表 3 に，初期フォルムと得られたフォルムをそれぞれ図 6 (a) と図 6 (b)に示寸. 両フォルムを比較すると, 得られたフォルムではダウンチューブとアッパーリアステーの径が大きくなり, やや 曲率を帯びた放物型のフォルムになっていることがわかる. また, 初期フォルムでは C 点応力は 13.24 (MPa)であ ったが, 最適化後の推定值では $1.73(\mathrm{MPa})$ と大きく減少している. なお, 最適化後のフォルムで再構造解析を行 うと, C点の最大応力は $2.53(\mathrm{MPa})$ となり, 推定值からやや増加したが，初期に対しては大きく減少した.

Table 3 Optimization result of case 1

\begin{tabular}{|c|c|c|c|c|c|c|c|c|c|c|c|c|c|}
\hline & \multicolumn{2}{|c|}{ Front fork } & \multicolumn{2}{|c|}{ Top tube } & \multicolumn{2}{|c|}{ Down tube } & \multicolumn{2}{|c|}{ Seat tube } & \multicolumn{2}{|c|}{ Upper rear stay } & \multicolumn{2}{|c|}{ Lower rear stay } & \\
\hline & $\mathrm{x}_{1}$ & $\mathrm{x}_{2}$ & $\mathrm{x}_{3}$ & $\mathrm{x}_{4}$ & $\mathrm{X}_{5}$ & $\mathrm{x}_{6}$ & $\mathrm{x}_{7}$ & $\mathrm{X}_{8}$ & $\mathrm{X}_{9}$ & $\mathrm{X}_{10}$ & $\mathrm{X}_{11}$ & $\mathrm{x}_{12}$ & \\
\hline Initial & 50 & 50 & 50 & 50 & 50 & 50 & 50 & 50 & 50 & 50 & 50 & 50 & \\
\hline \multirow[t]{2}{*}{ Optimal } & 50 & 50 & 50 & 50 & 76.6 & 80 & 50 & 50 & 55.2 & 58.3 & 50 & 50 & \\
\hline & $\mathrm{x}_{13}$ & $\mathrm{x}_{14}$ & $\mathrm{X}_{15}$ & $\mathrm{X}_{16}$ & $\mathrm{X}_{17}$ & $\mathrm{X}_{18}$ & $\mathbf{X}_{19}$ & $\mathrm{X}_{20}$ & $\mathrm{X}_{21}$ & $\mathrm{X}_{22}$ & $\mathrm{X}_{23}$ & $\mathrm{X}_{24}$ & Evaluation score \\
\hline Initial & 0 & 0 & 0 & 0 & 0 & 0 & 0 & 0 & 0 & 0 & 0 & 0 & 0.21 \\
\hline Optimal & 0 & 11.6 & 0 & 0 & 25 & 0 & 0 & 0 & 25 & 0 & 0 & 0 & 0.01 \\
\hline
\end{tabular}

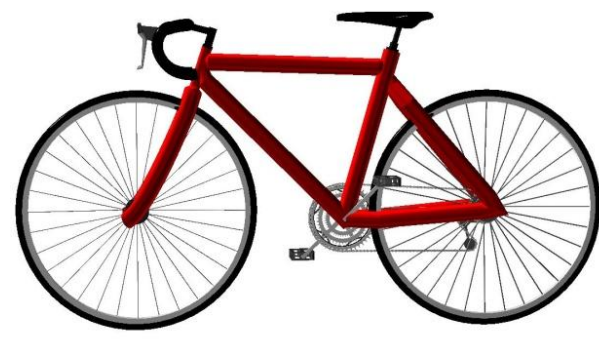

(a) Initial design

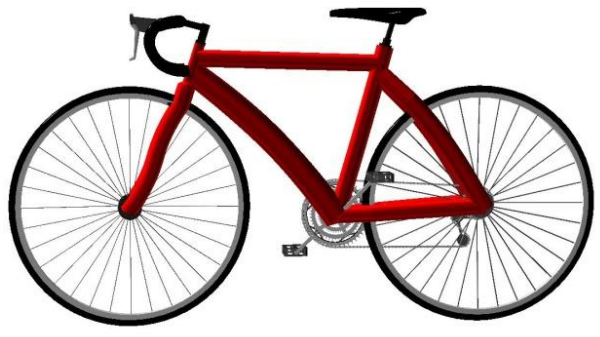

(b) Obtained design for minimization of "strength of C" Fig.6 Optimization result of case 1

\section{$3 \cdot 2 \cdot 2$ 挙動制約条件を含む応力の最小化（ケース 2)}

ケース 2 として，ケース 1 に重量の制約条件（重量 $\leq 0.5 ）$ を加えてC 点応力の最小化を行い，挙動制約の影響 を調べた. なお，重量の制約值 0.5 は 81 個のモデルの平均值を表す.

目的関数: $\quad \mathrm{C}$ 点応力 (最小化)

制約条件: $\quad 20 \leq x_{1} \sim x_{12} \leq 80,-25 \leq x_{13}, x_{15}, x_{17}, x_{19}, x_{21}, x_{23} \leq 25$,

$-20 \leq x_{14}, x_{16}, x_{18}, x_{20}, x_{22}, x_{24} \leq 20$,

重量 $\leq 0.5$ 
得られた結果に基づいてリモデリングしたフォルムを図 7 に示す．ケース 1 に比較して大きなフォルムの変更 は認められないが，ケース 2 で得られたフォルムではC点の応力への寄与が少ないフロントフォーク，トップチ ユーブ，ロアリアステーのフレームは細くなっていることがわかる. 重量の制約を加えることでC点応力の推定 值は $2.86(\mathrm{MPa})$ （再構造解析值は $3.22(\mathrm{MPa})$ ）となり，ケース 1 の值より増加することが確認された.

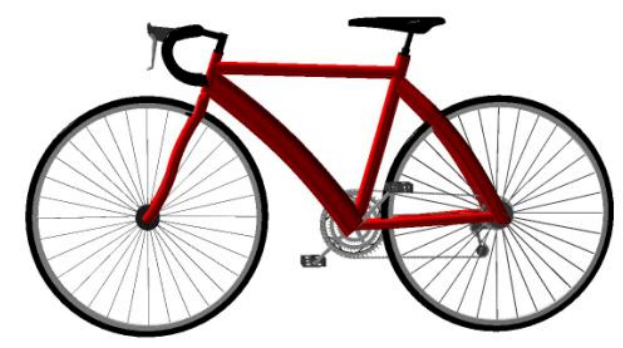

Fig.7 Optimization result of case 2

\section{$3 \cdot 2 \cdot 3$ 感性の最大化（ケース 3$)$}

ケース 3 では感性評価特性の 1 つである「格好いい」の最大化を目的に, 設計変数に式(13)から式(15)の側面制 約を与えて最適化計算を行った。

$$
\begin{array}{ll}
\text { 目的関数: } & \text { 格好いい (最大化) } \\
\text { 制約条件: } & 20 \leq x_{1} \sim x_{12} \leq 80,-25 \leq x_{13}, x_{15}, x_{17}, x_{19}, x_{21}, x_{23} \leq 25, \\
& -20 \leq x_{14}, x_{16}, x_{18}, x_{20}, x_{22}, x_{24} \leq 20
\end{array}
$$

得られた結果を表 4 に，リモデリング結果を図 8 に示すが，最適化計算により初期フォルムに比べ，車体後方 の3つのフレームが全体的に細くなっていることがわかる．また，シートチューブとロアリアステーは中点の回 転角が変動して曲点を有する $\mathrm{S}$ 字型フレームとなっていることがわかる. トップチューブとダウンチューブは中 点の位置が変動して放物型フレームとなり，精悍さを感じさせるフォルムとなっている．なお，このリモデリン

\begin{tabular}{|c|c|c|c|c|c|c|c|c|c|c|c|c|c|}
\hline & \multicolumn{2}{|c|}{ Front fork } & \multicolumn{2}{|c|}{ Top tube } & \multicolumn{2}{|c|}{ Down tube } & \multicolumn{2}{|c|}{ Seat tube } & \multicolumn{2}{|c|}{ Upper rear stay } & \multicolumn{2}{|c|}{ Lower rear stay } & \\
\hline & $\mathrm{x}_{1}$ & $\mathrm{x}_{2}$ & $\mathrm{x}_{3}$ & $\mathrm{x}_{4}$ & $\mathrm{X}_{5}$ & $\mathrm{x}_{6}$ & $\mathrm{x}_{7}$ & $\mathrm{x}_{8}$ & $\mathrm{X}_{9}$ & $\mathrm{x}_{10}$ & $\mathrm{x}_{11}$ & $\mathrm{x}_{12}$ & \\
\hline Initial & 50 & 50 & 50 & 50 & 50 & 50 & 50 & 50 & 50 & 50 & 50 & 50 & \\
\hline \multirow[t]{2}{*}{ Optimal } & 34.4 & 50 & 66.7 & 79.3 & 47.7 & 52.3 & 20 & 55.5 & 28.2 & 50 & 20 & 37.1 & \\
\hline & $\mathrm{x}_{13}$ & $\mathrm{X}_{14}$ & $\mathrm{x}_{15}$ & $\mathrm{x}_{16}$ & $\mathrm{x}_{17}$ & $\mathrm{x}_{18}$ & $\mathbf{X}_{19}$ & $\mathrm{X}_{20}$ & $\mathrm{X}_{21}$ & $\mathrm{X}_{22}$ & $\mathrm{X}_{23}$ & $\mathrm{X}_{24}$ & Evaluation score \\
\hline Initial & 0 & 0 & 0 & 0 & 0 & 0 & 0 & 0 & 0 & 0 & 0 & 0 & 0.64 \\
\hline Optimal & -4.8 & -2.5 & 25 & -6.8 & -25 & -3.7 & 0 & 20 & 1.5 & 2.8 & 0 & -20 & 1.56 \\
\hline
\end{tabular}
グ結果を見た被験者は「格好いい」という感想を述べた。

Table 4 Optimization result of case 3

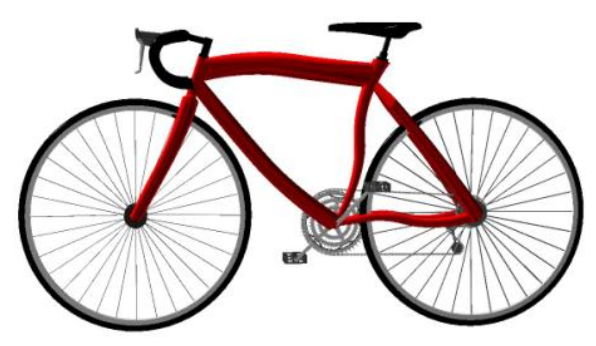

Fig.8 Optimization result of case 3 


\section{$3 \cdot 2 \cdot 4$ 挙動制約条件を含む感性の最大化（ケース 4）}

ケース 4 では, ケース 3 の目的関数と制約条件に，9つの挙動制約条件を加えて「格好いいの最大化を試み, 多挙動制約条件の影響を調べた. なお, 加えた感性と構造特性に関する制約值は全て平均以上を表す 0.5 とした. 得られた結果に基づいてリモデリング結果を図 9 に示す。多くの挙動制約条件を付加することで，ケース 3 とは かなり異なるフォルムとなっていることがわかる．制約を与え過ぎることにより，得られた結果が感性の設計条 件を適切に表現できているかの評価や解釈が難しくなることが確認された.

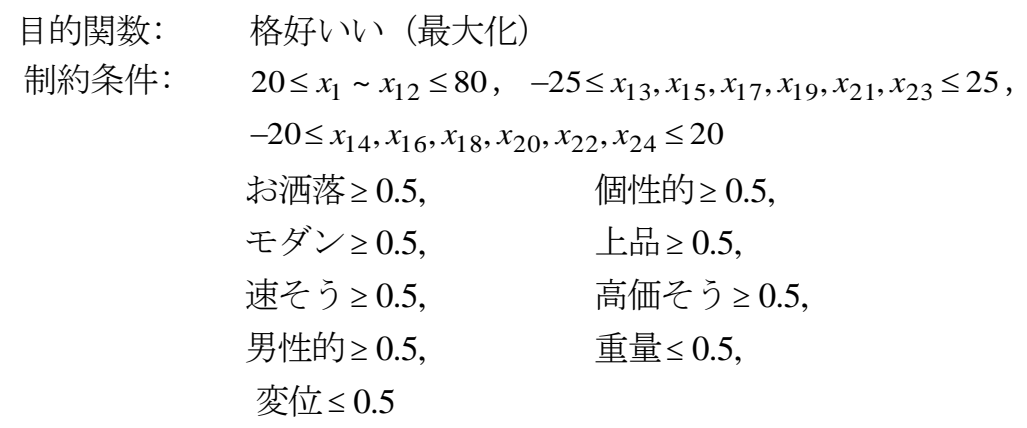

変位 $\leq 0.5$

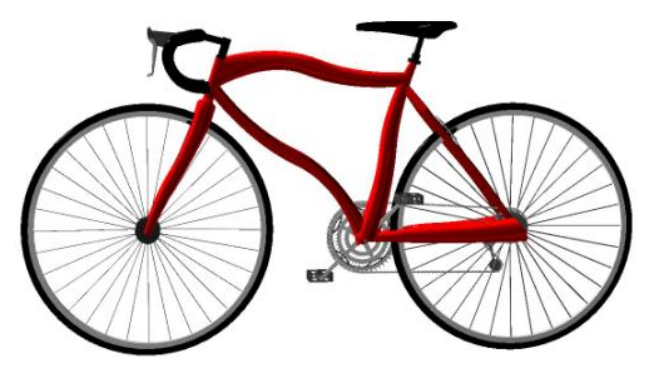

Fig.9 Optimization result of case 4

\section{$3 \cdot 3$ 感性評価と構造評価の多目的最適化計算結果}

感性と構造特性から複数の目的関数を設定することによって多目的最適化が可能となる. ベクトル目的関数の スカラー化には, 重み係数法を用い, 重み係数の組み合わせを変えることによりパレート最適フォルムを求めた. なお，全ての計算ケースにおいて，単一目的の場合と同様，最適化手法としては逐次 2 次計画法を用い，初期值 は各水準の中央值（フォルムは図 6 (a)）とした．以下に実施した 3 ケースの多目的最適化結果を示寸.

\section{$3 \cdot 3 \cdot 1$ 構造特性と感性の多目的最適化（ケース 5)}

構造特性と感性の目的関数の組合せとして,「変位」と「速そう」を評価関数に選び，多目的最適化計算を行 い，パレート解を求めることを行った，目的関数を式(28)に，制約条件を式(29)から (31)に示寸． なお，感性と 合わせた最大化行うため，「変位」最小化を「岡性」最大化として扱った．ここで，利，利はそれぞれ「岡性」 と「速そう」に乗ずる重み係数を表す.

$$
\begin{array}{ll}
\text { 目的関数: } & w_{1} \times \text { 岡性 }+w_{2} \times \text { 速そう（最大化） } \\
\text { 制約条件: } & 20 \leq x_{1} \sim x_{12} \leq 80,-25 \leq x_{13}, x_{15}, x_{17}, x_{19}, x_{21}, x_{23} \leq 25, \\
& -20 \leq x_{14}, x_{16}, x_{18}, x_{20}, x_{22}, x_{24} \leq 20
\end{array}
$$

重み係数の組合せを 5 通り (1) $w_{1}=1 \& w_{2}=0$, (2) $w_{1}=0.75 \& w_{2}=0.25$, (3) $w_{1}=0.5 \& w_{2}=0.5$, (4) $w_{1}=0.25 \& w_{2}=0.75$, (5) $\left.w_{1}=0 \quad \& \quad w_{2}=1\right)$ 設定し, 最適化計算を行った結果を基にリモデリングした結果を図 10 に示す. なお，図 10 (a) と(e)はそれぞれ(1)と（5)の場合の結果を示しており，「岡性」と「速そう」の単一目的での最大化に相当する.

「岡性」を最大化した場合, 全フレームのとも外形は上限值, もしくはそれに近い值となり, 重厚なフォルム 
となっているが，「速そう」を最大化した場合はフロントフォークからトップチューブ，リアステイ上部にかけ て太く，「速そう」をイメージさせるフォルムとなっている. 重み係数の組合せを変えた場合，その大きさに応 じて(a)と(e)のフォルムの特徵を重ね合わせた中間的なフォルムが得られ，「岡性」の重み係数が小さくなるにつ れてトップチューブとリアステイ上部を除くフレームの外径が小さくなり, 曲率も若干発生していることがわか る. 得られた結果のパレート空間を図 11 に示すが，初期フォルムに対し，得られたフォルムの両特性は各ケー スにおいて右側，上側にシフトとし，「岡性」と「速そう」の関係がトレードオフになっていることがわかる.

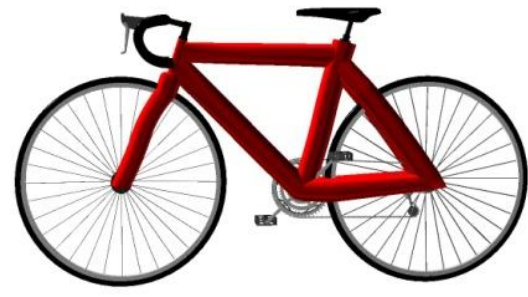

(a) "Rigidity" 1, "Fast" 0

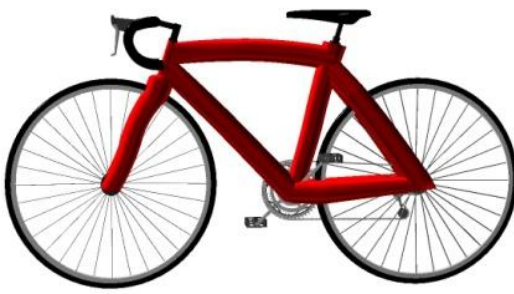

(b) "Rigidity" 0.75, "Fast" 0.25

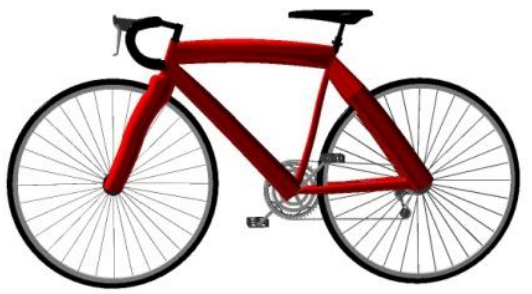

(c) "Rigidity" 0.5, "Fast" 0.5

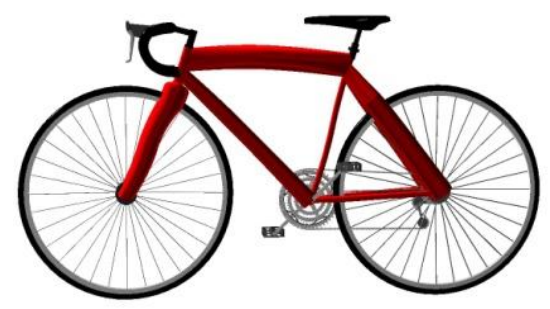

(d) "Rigidity" 0.25, "Fast" 0.75

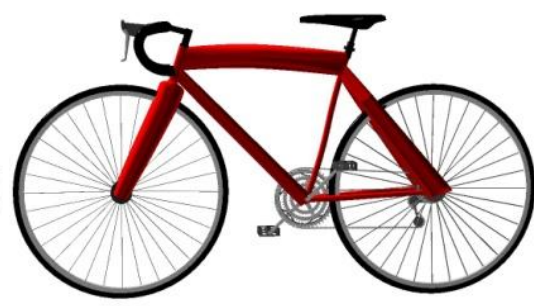

(e) "Rigidity" 0, "Fast" 1

Fig.10 Pareto solutions of case 5

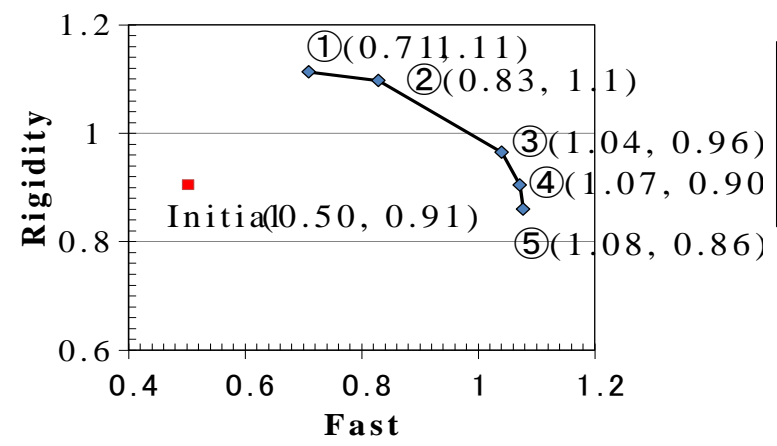

(1): Rigidity 1, Fast 0

(2): Rigidity 0.75 , Fast 0.25

(3): Rigidity 0.5 , Fast 0.5

(4): Rigidity0.25, Fast 0.75

(5): Rigidity 0 , Fast 1

Fig.11 Pareto space of case 5

\section{$3 \cdot 3 \cdot 2$ 感性の多目的最適化（ケース 6)}

ケース 6 では，感性同士の目的関数の組合せとして，「個性的」と「速そう」を評価関数に選び，多目的最適 化計算を試みた。式(32)の目的関数に対し，ケース 5 と同様，5通りの重み係数の組合せを設定し，同様の側面 制約条件を与えた。

$$
\text { 目的関数: } \quad w_{1} \times \text { 個性的 }+w_{2} \times \text { 速そう（最大化） }
$$

それぞれの重み係数の組合せに対して得られた結果を基にリモデリングした結果を図 12 に，パレート空間を 図 13 に示す.「個性的」を最大化した場合（図 12 (a)), トップチューブは細い(断面下限值) 変曲点を有する 
$\mathrm{S}$ 字型フレームとなり，他のフレームとの断面サイズ差で「個性的」を表現したフォルムとなっている．重み係 数の組合せを変えたフォルム（図 12 (b)～（d)）は直線基調の「速そう」最大化フォルム (図 12 (e) ) と形状の 特徵を重㸚わせた中間的なフォルムとなっていることがわかる．パレート空間を図 13 に示すが，初期フォル ムに対し，「個性的」と「速そう」の関係もトレードオフであるが，「速そう」の重みが大きくなるにつれパレー 卜曲線の非線形性が強くなっている。これはフレームがある程度直線基調になると今回の被験者は「速そう」の 違いを感じなくなることを示している.

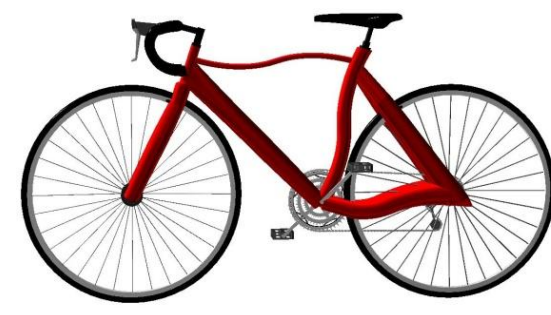

(a) "Individual" 1, "Fast" 0

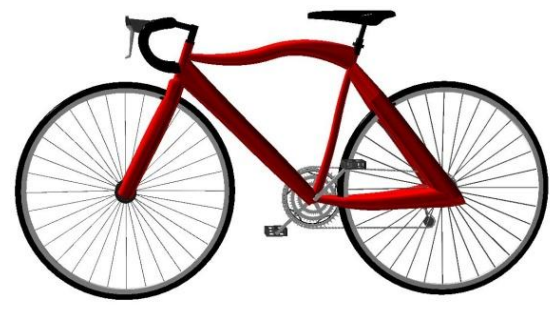

(b) "Individual" 0.75, "Fast" 0.25

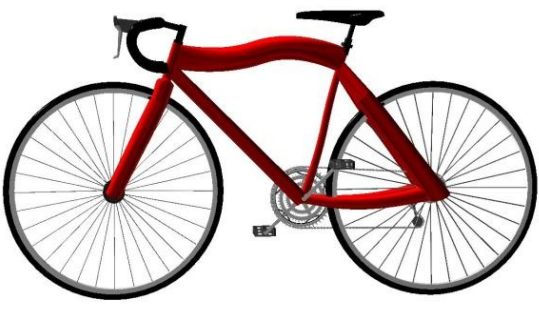

(c) "Individual" 0.5, "Fast" 0.5

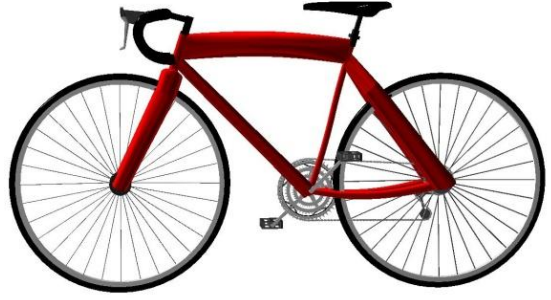

(d) "Individual" 0.25, "Fast" 0.75

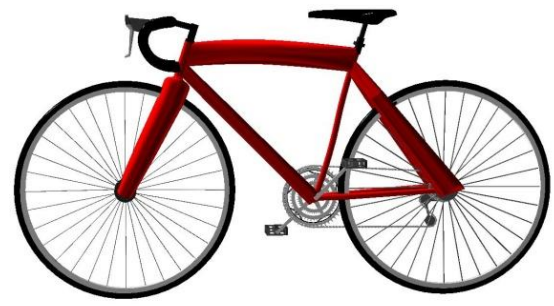

(e) "Individual" 0, "Fast" 1

Fig.12 Pareto solutions of case 6

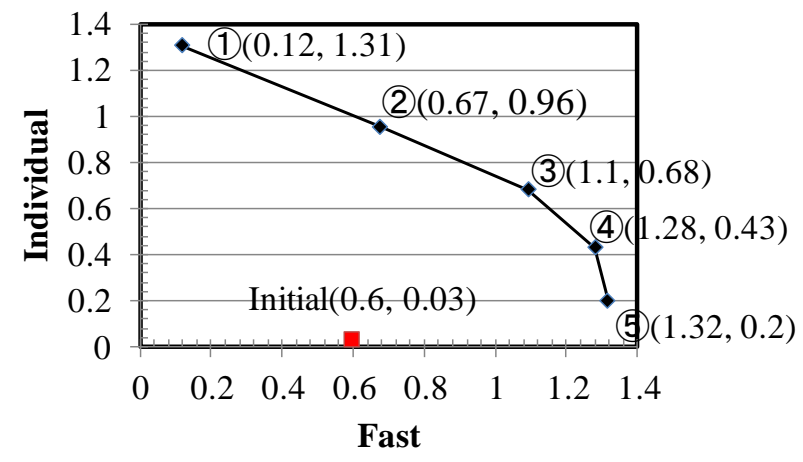

(1): Individual1, Fast0

(2): Individual0.75, Fast 0.25

(3): Individual0.5, Fast 0.5

(4): Individual0.25, Fast 0.75

(5): Individual0, Fast 1

Fig.13 Pareto space of case 6

\section{$3 \cdot 3 \cdot 3$ 感性の多目的最適化 (ケース 7)}

ケース 7 では, ケース 6 と同様，感性同士の目的関数の組合せの例として，「頑丈そう」と「上品」を評価関 数に選び，多目的最適化計算を試みた. 式(33)の目的関数に対し，ケース 6 と同様， 5 通りの重み係数の組合せ を設定し，同様の側面制約条件を与えた。 
それぞれの重み係数の組合せに対して得られたリモデリングした結果を図 12 に, パレート空間を図 13 に示 す.「上品」を最大化した場合（図 14 (a)), 中間的な断面サイズの直線基調のフレームとなっているのに対し，

「頑丈そう」を最大化した場合（図 14 (e) ), 断面サイズはほぼ上限で，変曲点を有する S 字型フレームが混在 する重厚なフレームとなっている．重み係数の組合せた場合（図 14 (b)～(d))，ケース 5，6 と同様，「上品」 最大化と「頑丈そう」最大の形状の特徽を重㸚合わせた中間的なフォルムとなっていることがわかる. パレート 空間を図 15 に示すが，初期フォルムに対し，「上品」と「頑丈そう」の関係もトレードオフの関係にあるが，パ レート曲線の形状は異なっている.

ここで示した多目的最適化の3つの計算例ではいずれも組み合わせた特性はトレードオフ関係を示したが，感 性ワードの組合せによっては異なった関係となることが推察され，その関係は本手法によって求めることが可能 である。

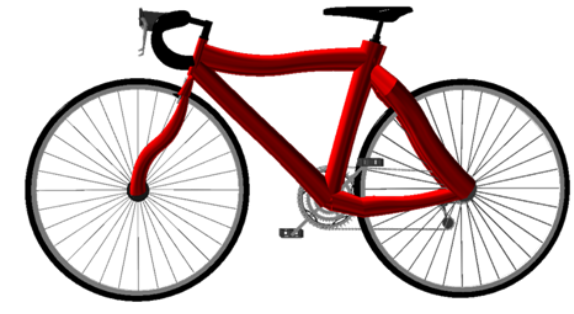

(a) “Tough" 1, "Elegant" 0

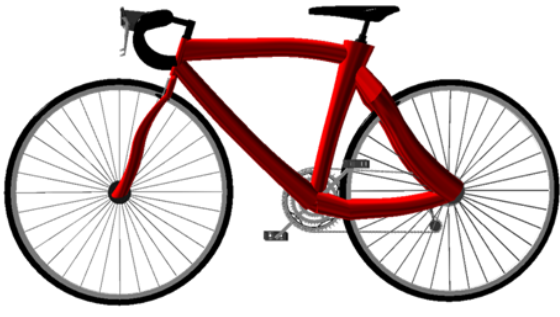

(b) “Tough" 0.75, "Elegant” 0.25

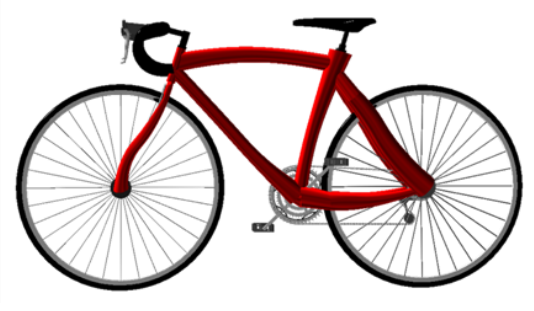

(c) “Tough" 0.5, "Elegant” 0.5

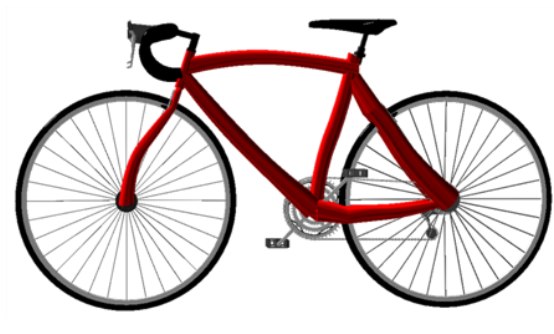

(d) “Tough" 0.25, "Elegant” 0.75

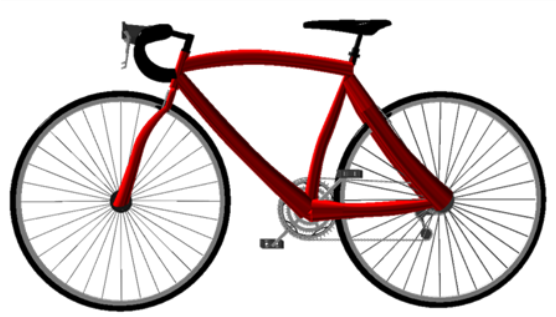

(e) “Tough" 0, "Elegant" 1

Fig.14 Pareto solutions of case 7

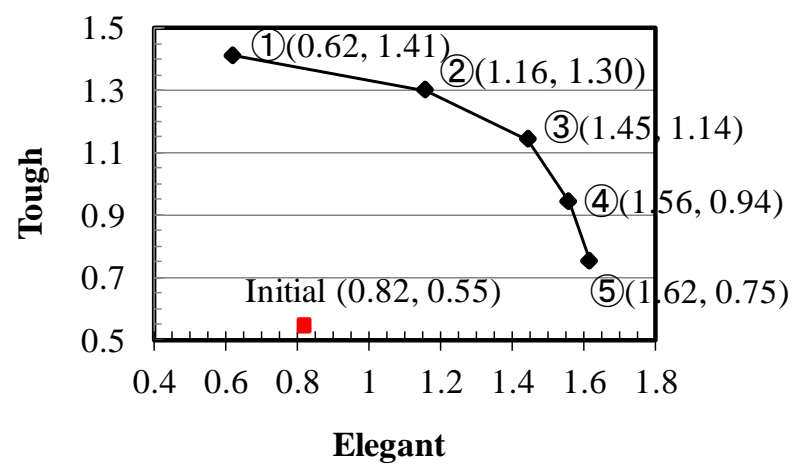
(1): Tough1, Elegant0
(2): Tough0.75, Elegant 0.25
(3): Tough0.5, Elegant 0.5
(4): Tough 0.25 , Elegant 0.75
(5): Tough0, Elegant1

Fig.15 Pareto space of case 7

\section{$3 \cdot 4$ 個人差の影響に関する考察}

本論文では前述のようにユーザーに合わせてフレームフォルムをカスタマイズすることを想定し, 被験者 1 人 
のデータに基づいた計算結果を示してきた. しかし, 異なる被験者に対してどのようなフォルムが得られるかに ついて考察を加えることはフォルムデザイン上の興味, 及び手法の信頼性の観点からも重要といえる. そこで, 本節では異なる被験者 4 名（いずれも 22 歳大学生）について行った結果を基に, 個人差の影響について考察す る.

ケース 3 の格好いい」について，4名の被験者の計算結果を基にリモデリングしたフォルムを図 16 に示す. （a）はケース 3（図 3）と同様のもの（被験者A とする），(b)から (c) は被験者BからEの結果を示している.（d) と (e)の結果は類似しているが，他はそれぞれ異なったフォルムとなっていることがわかる．「格好いい」という 感性ワードは個人の持つイメージに差異が大きく，それが反映された結果であるといえる.

一方，ケース 7 の評価関数の 1 つである「頑丈そう」や「軽そう」に対するアンケート結果は被験者によるば らつきが少なく（紙面の都合でデータは省略），個人差の比較的で難い感性ワードであった。評価に用いる感性 ワードによって，被験者間で共通のイメージを持ちやすいものと持ち難いものがあり，その程度も感性ワードに よって異なることが確認された.

本論文では 1 ユーザーの志向するカスタマイズフォルムを求めることを目的としたが，異なったコンセプトと して複数の被験者データを平均化し，統一的なフォルムとして求めることも可能である.

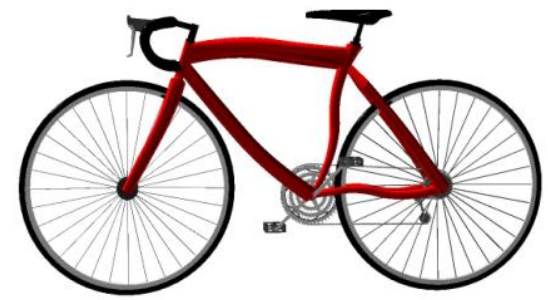

(a) Subject A (same as case 3)

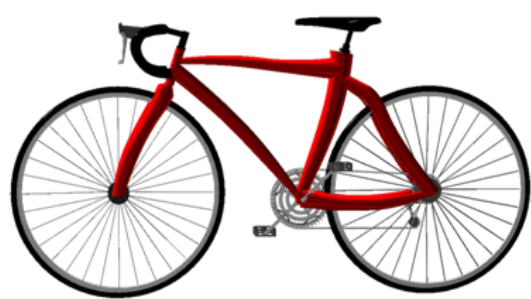

(b) Subject B

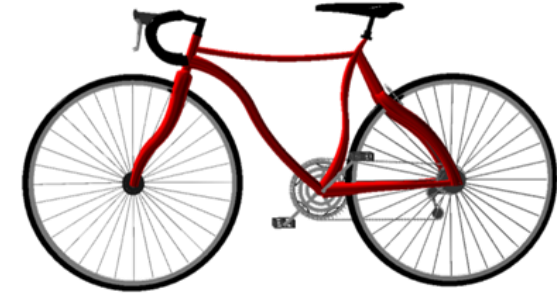

(c) Subject C

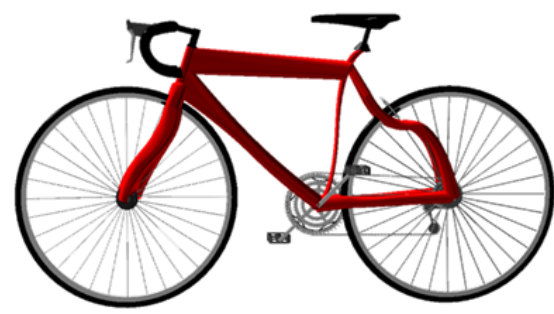

(d) Subject D

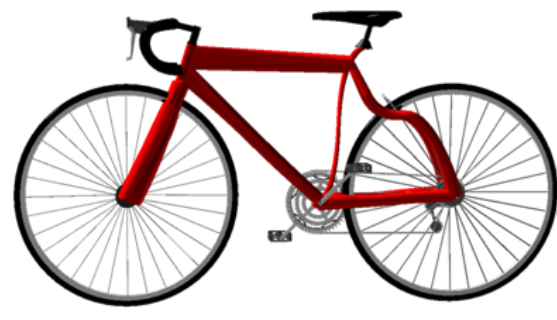

(e) Subject E

Fig.16 Optimization results of "Stylish" by other subjects

\section{4. 結言}

工業製品の設計において構造特性だけではなく感性を考慮した設計が益々重要になってきており，本論文では 既に確立されている構造最適化手法と感性評価手法を組从合わせ，構造特性と感性の両者を評価関数とする最適 設計法に関して, 曲線を許容したロードバイクのフレームを例に, 感性を考慮した構造最適化手法を提示した. 各フレームの両端の外径，中心点の位置及び回転角度を設計変数とし， $\mathrm{L}_{81}$ 直交表と応答曲面法を利用して感性と 構造特性の推定式を求めた. 感覚的で曖昧さを含む感性に関する評価は 3 次元 C Gモデルを作成し, 感性ワード に対して工学的手法II類を用いて定量化することにより行った．また，強度と岡性，重量からなる構造特性はは り要素モデルを作成し，有限要素法を利用して求めた．各特性に対し， 2 次の応答曲面を求め，目的関数と制約 条件を種々組み合わせることにより感性を考慮した単目的，または多目的の構造最適化計算を行い，最適フォル ム，もしくはパレート最適フォルムを求め，得られた結果を C Gソフトウェアでリモデリングした. 感性には個 人差があり， 1 被験者に限った場合であっても数值化された值は曖昧さを含んでいるが，本手法が感性と構造特 性の両者を評価関数にした最適設計問題に対し，良好に機能し妥当なフォルムが得られることを計算例を通して 
確認した．本研究ではロードバイクを例としたが，提示した手法は別の種類の自転車や他の工業製品への応用も 可能であり，今後，適用を検討する.

\section{謝 辞}

本研究は（財） J K Aの自転車等機械工業振興事業の補助金にて実施を致しました．記して厚く感謝の意を表 します。

\section{文献}

(1) Nagamachi, M. and Lokman, A. M., Innovation of KANSEIENGINEERING (2011), CRC Press.

(2) Nagamachi, M. (ed), KANSEI/AFFECTIVE ENGINEERING (2011), CRC Press.

(3) 長町三生, 感性商品学 : 感性工学の基礎と応用，(1993), 海文堂出版.

（4）勝山信之，山川宏，“遺伝的アルゴリズムによる感性を考慮した設計の遺伝と進化に関する研究”，日本機械学会 第 3 回設計工学・システム部門講演会講演論文集 (1993), pp105-110.

（5）荒川雅生，Jouchee, K.，萩原一郎，山川宏，“定性的な感性評価に基づく定性的な最適設計に関する研究：高能率 を引き出す椅子の開発”，日本機械学会論文集 C 編, Vol. 64, No.622 (1998), pp.2162-2168.

（6）柳澤秀吉, 村上存, 大富浩一, 穂坂倫佳, “感性の多様性を考慮した感性品質の定量化手法（製品音の設計におけ る感性品質の定量化一の適用)”，日本機械学会論文集 C 編, Vol. 74, No.746 (2008), pp.273-282.

（7）茅原崇徳, 山崎光悦, 伊藤隆一, “アルミボトル口径の飲みや寸さ評価法に関する基礎的検討”, 日本機械学会論文 集 C 編, Vol. 74, No. 737 (2008), pp. 134-141.

（8）茅原崇徳，山崎光悦，“アルミボトル口径の飲みや寸さ評価法に関する基礎的検討，第 2 報，飲みやすさ評価関数 の提案”, 日本機械学会論文集 C 編, Vol. 75, No.755 (2009), pp.2051-2058.

(9) Han, J., Yamazaki, K., Itoh, R. and Nishiyama, S. , "Multiobjective optimization of a two-piece aluminum beverage bottle considering tactile sensation of heat and embossing formability" , Structural and Multidisciplinary Optimization, Vol. 32, No. 2 (2006), pp.141-151.

（10）韓晶，西山貞雄，山崎光悦，伊藤隆一，“開缶時の指掛かり性を考慮した飲料用アルミ午蓋の設計”，日本機械学会 論文集 A 編, Vol. 73, No. 733 (2007), pp. 1095-1102.

(11) 安達瑛二, 高榎義宏，“感性評価を含む多目的満足設計”，日本機械学会論文集 C 編，Vol. 63，No. 605 (1997), pp. $279-284$.

（12）柴田滝也，堤和敏，“建築と空間設計の感性化” ，電子情報通信学会誌，Vol. 92, No.11 (2009), pp. 985-9879.

（13）堤和敏、太田優子、佐々木啓介, “感性を考慮した建物屋根形態創生に関する研究”,構造工学論文集，Vol. 51B (2005), pp.1-6.

（14）内山直子，柴田滝也，“都市景観と建築物との調和分析とモデル化に関する研究：住民参加を支援するマルチモー ダルな感性検索システムの構築法”，日本建築学会計画系論文集 Vol. 73, No. 623 (2008), pp. 241-248.

(15) 山際央明，柴田滝也，“データベースを用いたインテリア・コーディネート・エージェントに関する研究--リビン グに調和する 3 次元家具データ検索システム”，感性工学研究論文集 Vol. 7, No. 4 (2008), pp. 685-692.

(16) Furuta, H., Maeda, K. and Watanabe, E., “Application of Genetic Algorithm to Aesthetic Design of Bridge Structures” , Computer-Aided Civil and Infrastructure Engineering, Vol. 10, No. 6 (1995), pp.415-421.

(17) 白木 渡, 野田英明, 長町三生, 松原雄平, 安達 誠, “アーチ橋の感性データベースの構築とその景観評価への応 用”，構造工学論文集，Vol.45A (1999), pp.553-560.

（18）保田敬一，白木渡，“合意形成を目指した林橋景観の感性 DBによる景観評価・設計支援システムの構築”，土木学 会論文集A，Vol. 64, No. 4 (2008), pp. 889-904.

(19) Myers, R. H. and Montgomery, D. C., Response Surface Methodology (2 ${ }^{\text {nd }}$ edition), (2002), John Wiley \& Sons.

（20）柏村孝義，白鳥正樹，于強，実験計画法による非線形問題の最適化 (1998)，朝倉書店.

(21) JIS D9401 “自転車一フレーム”, 而振性試験. 